\title{
Пембролізумаб - перша лінія терапії для пацієнтів з поширеним недрібноклітинним раком легені як у моно-, так і в комбінованому режимі
}

DOI: $10.32471 /$ clinicaloncology.2663-466X.37-1.27293

\begin{abstract}
Резюме. Розробка інгібіторів контрольних точок (чекпойнтів) імунної відповіді радикально змінила підходи до лікування пацієнтів із поширеним недрібноклітинним раком легені (НДРЛ), що призвело до покращення клінічних результатів терапії. Пембролізумаб - гуманізоване моноклональне антитіло, що показане в якості терапії першої лінії у пацієнтів із поширеним НДРЛ та високим рівнем експресії PD-L1 (не менше ніж 50\% за шкалою пропорції пухлини (tumor proportion score - TPS). Пембролізумаб у комбінації з хіміотерапією продемонстрував кращі клінічні результати порівняно з хіміотерапією в якості терапії першої лінії у цієї групи пацієнтів. Однак мало відомо про значення додавання хіміотерапії до лікування пембролізумабом у цих пацієнтів. Нижче наведено огляд літератури, в якому представлені дані щодо непрямого порівняння застосування пембролізумабу в комбінації з хіміотерапією та монотерапії пембролізумабом. Розглядалися загальна виживаність, виживаність без прогресування захворювання та рівень об'єктивної відповіді. Так, наведені дані метааналізу, який включав 5 рандомізованих клінічних досліджень, в яких взяли участь майже 1300 пацієнтів. Прямий метааналіз показав, що як пембролізумаб разом із хіміотерапією, так і монотерапія пембролізумабом покращували клінічні результати порівняно з хіміотерапією. Непряме порівняння продемонструвало, що пембролізумаб разом із хіміотерапією був кращий за монотерапію пембролізумабом за показниками об'єктивної відповіді та виживаності без прогресування захворювання. Також виявлена тенденція до покращення загальної виживаності. Таким чином, додавання хіміотерапії до пембролізумабу ще більше покращує результати терапії пацієнтів із поширеним НДРЛ та високим рівнем експресії PD-L1 - TPS щонайменше 50\%.
\end{abstract}

Ключові слова: недрібноклітинний рак легені; ліганд рецептора програмованої смерті клітин-1 (PD-L1); пембролізумаб; хіміотерапія; перша лінія терапії

Недрібноклітинний рак легені (НДРЛ) - поширене злоякісне новоутворення, що є причиною понад 1,8 млн випадків смерті щороку у всьому світі. Відповідно до даних Всесвітньої організації охорони здоров'я, рак легені займає 1-шу позицію за показником смертності серед чоловіків, з 1,2 млн випадків смерті на рік, та 4-те - за кількістю нових випадків - 2,1 млн ( $28 \%$ усіх випадків онкопатології). Хоча рівень захворюваності на рак легені знижується у чоловіків, він продовжує зростати у жінок - з 3,6\% у 1980 р. до 19,2\% в наші дні через зміну звичок щодо куріння [1].

У минулому медіана загальної виживаності пацієнтів iз поширеним (неоперабельним або метастатичним) НДРЛ становила 8-12 міс [2, 3]. На щастя, за останні 10 років вдалося досягти помітного поліпшення ситуації за рахунок збільшення кількості ефективних методів терапії, що значно покращило клінічні результати, які обіцяють істотне зниження смертності, пов'язаної з НДРЛ [4-6].

Нові імунотерапевтичні препарати - інгібітори контрольних точок (чекпойнтів) імунної відповіді, такі як пембролізумаб, відіграють важливу роль у покращенні результатів терапії пацієнтів із поширеним НДРЛ протягом останніх років.

Пембролізумаб є гуманізованим моноклональним антитілом, що блокує взаємодію між PD-1 (рецептор запрограмованої смерті клітин-1, programmed cell death-1) та PD-L1 i PDL2 (ліганди рецептора запрограмованої смерті клітин-1 та -2, programmed cell death-ligand-1, -2), запускаючи інгібування імунної відповіді, опосередкованої PD-1, включаючи протипухлинну імунну відповідь. Зв'язування ліганда PD-1 (PDL1 i PD-L2) із рецептором PD-1, що міститься у T-клітинах, інгібує проліферацію Т-клітин і продукцію цитокінів. Активізація PD-1 ліганда відбувається у деяких пухлинах, і передача сигналів цим шляхом може сприяти гальмуванню активного Т-лімфоцитарного контролю пухлин [1].

Наразі монотерапія пембролізумабом замінила хіміотерапію препаратами платини в якості першої лінії лікування у пацієнтів із поширеним НДРЛ із високим рівнем експресії PD-L1 - не менше ніж 50\% за шкалою пропорції пухлини (tumor proportion score - TPS) [4]. У пацієнтів з невідомим рівнем експресії PD-L1 пембролізумаб разом із хіміотерапією є ефективнішим порівняно тільки з хіміотерапією [7]. Однак чи може комбінація пембролізумабу та хіміотерапії додатково покращити клінічні результати порівняно з монотерапією пембролізумабом, залишається під питанням через відсутність порівняльних досліджень.

Нещодавно опубліковано метааналіз, покликаний пролити світло на це питання. У ході означеного метааналізу було вивчено ефективність пембролізумабу в комбінації з хіміотерапією порівняно з монотерапією пембролізумабом в якості першої лінії терапії пацієнтів із поширеним НДРЛ та високим рівнем експресії PD-L1 (TPS $\geqslant 50 \%$ ), використовуючи непрямий порівняльний метааналіз [8].

Так, у метааналіз було включено 5 рандомізованих клінічних досліджень, в яких сумарно взяли участь 1289 пацієнтів [4, 9-12]. Основні характеристики та результати вказаних досліджень наведені у таблиці. Три клінічні дослідження вивчали пембролізумаб в комбінації з хіміотерапією порівняно з хіміотерапією та два клінічні дослідження вивчали ефективність монотерапії пембролізумабом порівняно з хіміотерапією. Усі клінічні дослідження використовували тест 22C3 pharmDx assay (Agilent Technologies) для оцінки рівня експресії PDL1 імуногістохімічний метод. У всіх вказаних клінічних дослідженнях застосовували стандартні схеми хіміотерапевтичного лікування відповідно до методичних рекомендацій. Середній час спостереження становив 7,8-23,9 міс. Усі 5 клінічних досліджень надавали дані щодо рівня об'єктивної відповіді, дані щодо загальної виживаності та виживаності без прогресування захворювання не наводилися у дослідженні KEYNOTE-021 для когорти G [9].

Розглянемо результати прямого метааналізу [8]. Значна різниця щодо рівня об'єктивної відповіді виявлена на користь пембролізумабу в комбінації з хіміотерапією порівняно з хіміотерапією (відношення ризиків (ВР) $=2,16$; $95 \%$ ДІ 1,66-2,82; $\mathrm{p}<0,001 ;$ гетерогенність даних, $\mathrm{p}=0,441)$. А для монотерапії пембролізумабом порівняно з хіміотерапією об'єднане ВР становило 1,33 (95\% ДI 1,11-1,58; p=0,002; гетерогенність даних, $\mathrm{p}=0,260)$ (рисунок A).

Щодо виживаності без прогресування захворювання пембролізумаб в комбінації з хіміотерапією продемонстрував значне зниження ризику прогресування захворювання порівняно з хіміотерапією (ВР 0,36; 95\% ДІ 0,27-0,48; z=7,03, 
Таблиця. Характеристики досліджень, в яких порівнювався пембролізумаб в комбінації з хіміотерапією/монотерапія пембролізумабом з хіміотерапією. Адаптовано із 7

\begin{tabular}{|c|c|c|c|c|c|c|c|c|c|c|c|}
\hline \multirow[b]{2}{*}{ 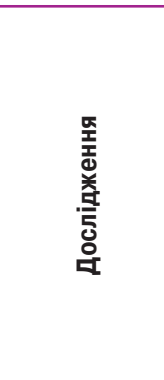 } & \multirow{2}{*}{ 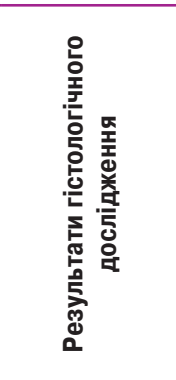 } & \multirow{2}{*}{ 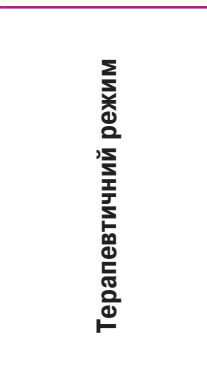 } & \multicolumn{2}{|c|}{$\begin{array}{c}\text { Кількість паці- } \\
\text { єнтів }\end{array}$} & \multicolumn{2}{|c|}{$\begin{array}{c}\text { Кількість паці- } \\
\text { єнтів, що від- } \\
\text { повіли на ліку- } \\
\text { вання } \\
\end{array}$} & \multirow{2}{*}{ 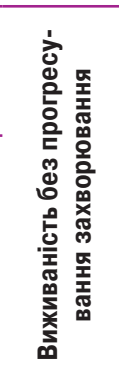 } & \multirow{2}{*}{ 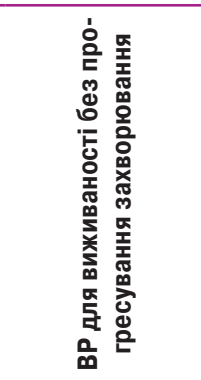 } & \multirow{2}{*}{ 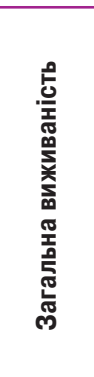 } & \multirow{2}{*}{ 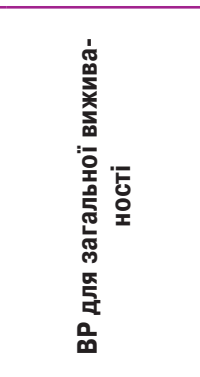 } & \multirow{2}{*}{ 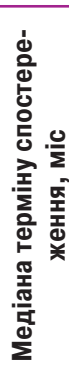 } \\
\hline & & & 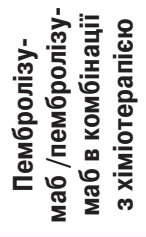 & 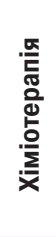 & 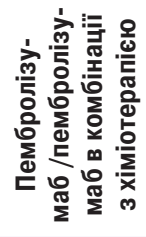 & 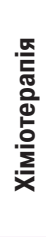 & & & & & \\
\hline $\begin{array}{l}\text { KEYNOTE-189 } \\
2018\end{array}$ & $\begin{array}{c}\text { Неплоскоклі- } \\
\text { тинний }\end{array}$ & $\begin{array}{c}\text { Пембролізу- } \\
\text { маб в комбінації } \\
3 \text { хіміотерапією } \\
\text { порівняно } 3 \text { хіміо- } \\
\text { терапією }\end{array}$ & 132 & 70 & 81 & 16 & - & $0,36(0,25-0,52)$ & - & $0,42(0,26-0,68)$ & 10,5 \\
\hline $\begin{array}{l}\text { KEYNOTE-407 } \\
2018\end{array}$ & $\begin{array}{c}\text { Плоскоклітин- } \\
\text { ний }\end{array}$ & $\begin{array}{c}\text { Пембролізу- } \\
\text { маб в комбінації } \\
3 \text { хіміотерапією } \\
\text { порівняно } 3 \text { хіміо- } \\
\text { терапією }\end{array}$ & 73 & 73 & 44 & 24 & 8,0 vs 4,2 & $0,37(0,24-0,58)$ & - & $0,64(0,37-1,10)$ & 7,8 \\
\hline $\begin{array}{l}\text { KEYNOTE-024 } \\
2016,2017\end{array}$ & $\begin{array}{c}\text { Плоскоклітин- } \\
\text { ний та неплос- } \\
\text { коклітинний }\end{array}$ & $\begin{array}{c}\text { Пембролізу- } \\
\text { маб порівняно } \\
\text { із хіміотерапією }\end{array}$ & 154 & 151 & 70 & 45 & $\begin{array}{c}10,3 \text { vs } \\
6,0\end{array}$ & $0,50(0,37-0,68)$ & $\begin{array}{c}30,0 \text { vs } \\
14,2\end{array}$ & $0,63(0,47-0,86)$ & 25,2 \\
\hline $\begin{array}{l}\text { KEYNOTE-042 } \\
2018\end{array}$ & $\begin{array}{c}\text { Плоскоклітин- } \\
\text { ний та неплос- } \\
\text { коклітинний }\end{array}$ & $\begin{array}{c}\text { Пембролізу- } \\
\text { маб порівняно } \\
\text { із хіміотерапією }\end{array}$ & 299 & 300 & 118 & 96 & 7,1 vs 6,4 & $0,81(0,67-0,99)$ & $\begin{array}{c}20,0 \text { vs } \\
12,2\end{array}$ & $0,69(0,56-0,85)$ & 12,8 \\
\hline
\end{tabular}

$\mathrm{p}<0,001 ;$ неоднорідність, $\mathrm{p}=0,925)$. У той час як монотерапія пембролізумабом не продемонструвала значного поліпшення виживаності без прогресування захворювання (HRpem/xiмio, 0,65; 95\% ДІ 0,40-1,04; $\mathrm{z}=1,82, \mathrm{p}=0,069$; гетерогенність даних, $\mathrm{p}=0,009$ ) (рисунок Б). Що стосується загальної виживаності, то як пембролізумаб в комбінації з хіміотерапією (ВР 0,$51 ; 95 \%$ ДІ $0,35-0,72 ; \mathrm{z}=3,71, \mathrm{p}<0,001)$, так і монотерапія пембролізумабом (ВР 0,$67 ; 95 \%$ ДІ $0,56-0,80 ; z=4,57, p<0,001)$ значно знижували ризик смерті порівняно з хіміотерапією (рисунок В).

На рисунку Г показано результати непрямого порівняння ефективності пембролізумабу в комбінації з хіміотерапією та монотерапії пембролізумабом [8]. Результати свідчать, що пацієнти, які отримували пембролізумаб в комбінації iз хіміотерапією, мали кращі клінічні результати, включаючи рівень об'єктивної відповіді (ВР 1,62, 95\% ДІ 1,18-2,23; $\mathrm{p}=0,003)$ та виживаність без прогресування захворювання (ВР $0,55,95 \%$ ДІ 0,32-0,97; p=0,037), ніж ті, які отримували монотерапію пембролізумабом. Однак спостерігалася лише тенденція до поліпшення загальної виживаності при застосуванні пембролізумабу в комбінації з хіміотерапією порівняно з монотерапією пембролізумабом (ВР 0,76, 95\% ДІ 0,51-1,14; $\mathrm{p}=0,184)$.

Таким чином, пембролізумаб в комбінації з хіміотерапією перевершує монотерапію пембролізумабом в якості лікування першої лінії у пацієнтів із поширеним НДРЛ та високим рівнем експресії PD-L1 (TPS 》50\%) щодо рівня об'єктивної відповіді та виживаності без прогресування захворювання. Тенденція до покращення загальної виживаності відмічена також для пембролізумабу в комбінації з хіміотерапією.

PD-L1 - це визначений біомаркер для відбору пацієнтів, для яких показана монотерапія пембролізумабом в якості першої лінії лікування [4]. 3 одного боку, приємно думати, що монотерапія пембролізумабом має кращу переносимість, виявляючи при цьому вищу ефективність щодо загальної виживаності пацієнтів із високим рівнем експресії PD-L1 (TPS $\geqslant 50 \%$ ). 3 іншого боку, менше 50\% пацієнтів із поширеним НДРЛ отримують другу лінію терапії через швидке погіршення стану при прогресуванні захворювання [13]. Тому максимізація шансів отримати позитивну реакцію на лікування вже при першій лінії терапії та відтермінування розвитку резистентності до лікарських засобів є клінічно важливими. Іншим викликом є внутрішньопухлинна гетерогенність експресії PD-L1 [14]. Зразки, отримані за допомогою тонкої голки для аспірації, не представляють всієї генетичної різноманітності пухлини, і висока експресія PD-L1, виявлена в цих умовах, може бути хибнопозитивною. Крім того, граничне значення $50 \%$ не є ідеальним для стратифікації користі для пацієнтів. Ретроспективне дослідження показало, що пембролізумаб демонстрував помірну ефективність лише у пацієнтів з рівнем експресії PD-L1 TPS=50-74\% (рівень об'єктивної відповіді 21,6\%; виживаність без прогресії захворювання 3,2 міс; загальна виживаність 20,6 міс) або 50-89\% (рівень об'єктивної відповіді 25,2\%; виживаність без прогресії захворювання 3,7 міс; загальна виживаність 15,2 міс) [15], що вказує на те, що популяція хворих, які дійсно отримають користь від застосування пембролізумабу, може мати ще вищі рівні експресії PD-L1, ніж прийнято використовувати для визначення пацієнтів, яким показане лікування пембролізумабом. Ці виклики, ймовірно, пояснюють, чому монотерапія пембролізумабом зумовлює відповідь на лікування в 40-45\% випадків і чому розподіл кривих виживаності відбувається уповільнено [10, 12].

Об'єднаний аналіз показав, що монотерапія пембролізумабом несуттєво покращила виживаність без прогресії порівняно 3 хіміотерапією, тоді як пембролізумаб в комбінації з хіміотерапією продемонстрував значно кращі результати порівняно 3 хіміотерапією з точки зору всіх досліджуваних результатів, включаючи рівень об'єктивної відповіді, виживаність без прогресії захворювання та загальну виживаність. Непряме порівняння демонструє, що додавання хіміотерапії до терапії пембролізумабом ще більше підвищує шанс отримати відповідь на лікування - на 62\%. Крім того, ризик прогресування захворювання та смерті знижується на 45 та $24 \%$ відповідно. Хоча поліпшення загальної виживаності при застосуванні пембролізумабу в комбінації з хіміотерапією порівняно з монотерапією пембролізумабом не є статистично значущим, це, ймовірно, обумовлено короткою тривалістю спостереження у дослідженні KEYNOTE-407 [11]. Необхідний аналіз оновлень цього дослідження зі збільшеним терміном спостереження. Результати, отримані в ході вказаного метааналізу, підтверджують гіпотезу про те, що хіміотерапевтичні засоби можуть за певних обставин чинити імунопотенціювальний ефект. 
$\mathrm{A} O \mathrm{~B}$

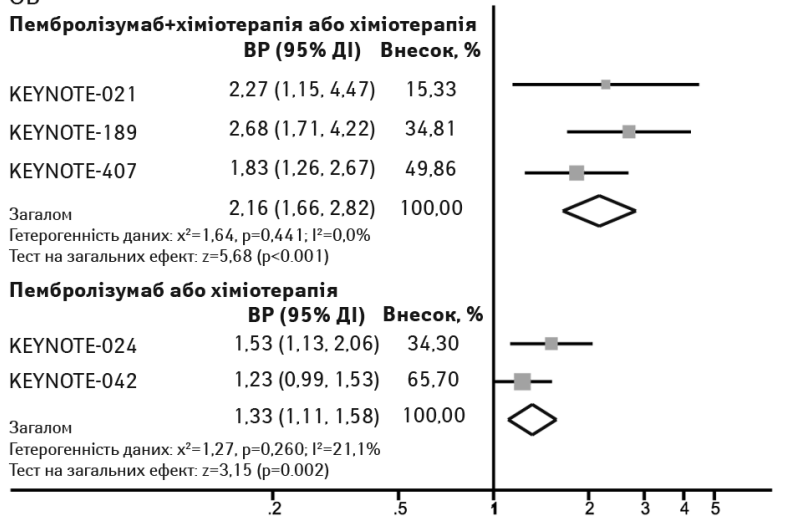

B 3в

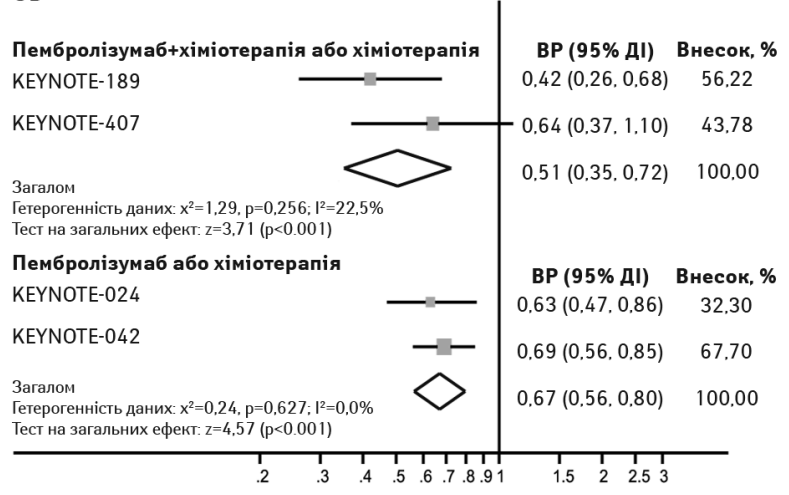

Б

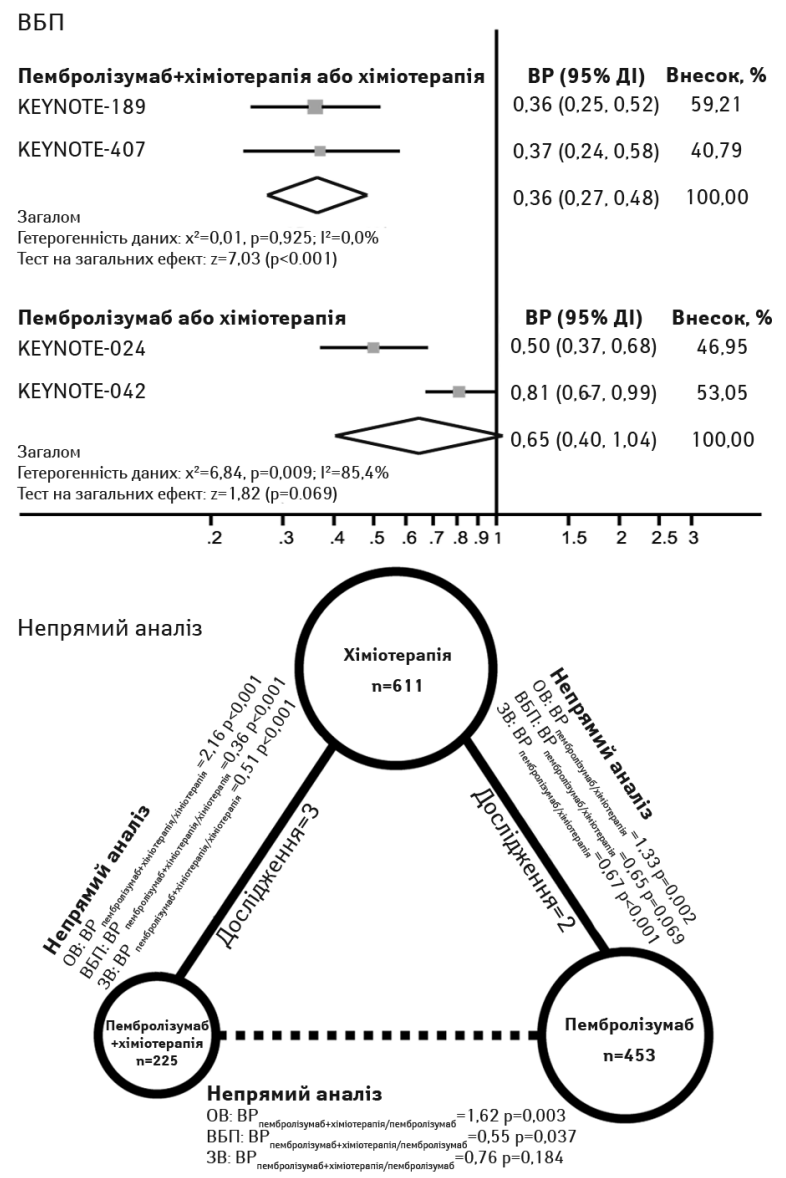

Рисунок. Прямі порівняння між пембролізумабом в комбінації з хіміотерапією або монотерапією пембролізумабом з хіміотерапією та непрямим порівнянням між пембролізумабом в комбінації з хіміотерапією порівняно з монотерапією пембролізумабом. На рисунках А, Б та В показано форест-плот з наведенням ВР при прямому порівнянні рівня об'єктивної відповіді (А), виживаності без прогресування захворювання (Б) та загальної виживаності (В) при терапії пембролізумабом в комбінації з хіміотерапією або монотерапією пембролізумабом. Розмір маркерів даних (квадратів) відповідає фазі дослідження в метааналізі. Горизонтальна лінія, що перетинає квадрат, представляє 95\% ДІ. Ромби представляють оцінений загальний ефект на основі метааналізу. На рисунку Г суцільні лінії показують наявність прямих порівнянь між схемами лікування, а пунктирна лінія - непряме порівняння між пембролізумабом в комбінації з хіміотерапією та монотерапією пембролізумабом. Розмір кола відповідає кількості пацієнтів.

Виходячи з цих даних, може бути доцільним рекомендувати пацієнтам з великим об’ємом пухлини застосовувати комбіновану терапію для отримання більш вираженої та тривалої реакції на лікування, тоді як пацієнти з невеликим об'ємом пухлини або з дуже високим рівнем експресії PD-L1 можуть отримувати лише монотерапію пембролізумабом.

Слід підкреслити високу якість вихідних даних, що аналізувалися в ході цього метааналізу. Вихідні дані були отримані з 5 добре спланованих рандомізованих контрольованих клінічних досліджень за участю більше ніж 1000 пацієнтів. Експериментальний препарат та методи визначення експресії PD-L1 однакові. Таким чином, метааналіз міг би подолати проблему недостатньої потужності кожного окремого дослідження шляхом об’єднання даних та мінімізації неоднорідності між дослідженнями. Однак метааналіз має й певні обмеження. Зокрема, метааналіз опирається на опубліковані результати, а не на дані окремих пацієнтів, бракувало даних для порівняння head-to-head. Крім того, дані щодо ефективності застосування пембролізумабу в комбінації з хіміотерапією отримують внаслідок аналізу даних підгруп, тому інтерпретація результатів потребує додаткової обережності. Однак не виявлено значущої різниці між дослідженнями застосування пембролізумабу в комбінації з хіміотерапією та дослідженнями монотерапії пембролізумабом, включеними в аналіз, що робить опосередковане порівняння певною мірою надійним. Враховуючи ці обмеження, для прямого порівняння ефективності застосування пембролізумабу в комбінації з хіміотерапією з монотерапією пембролізумабом потрібно буде проводити рандомізовані дослідження. Майбутні дослідження також повинні вивчити оптимальне значення рівня експресії PD-L1 для відбору пацієнтів, вище якого монотерапія пембролізумабом не поступається за ефективністю застосування пембролізумабу в комбінації з хіміотерапією.

Підбиваючи підсумки, слід підкреслити, що додавання хіміотерапії до лікування пембролізумабом в якості терапії першої лінії ще більше покращує результати пацієнтів із поширеним НДРЛ та високим рівнем експресії PD-L1 (TPS $\geqslant 50 \%$ ). Враховуючи доведену перевагу щодо виживаності, керовану токсичність та уникнення необхідності відбору пацієнтів на основі рівня експресії PD-L1, лікарі-онкологи можуть віддати перевагу застосуванню пембролізумабу в комбінації з хіміотерапією у пацієнтів без протипоказань, особливо для хворих з великим об'ємом пухлини.

\section{СПИСОК ВИКОРИСТАНОЇ ЛІТЕРАТУРИ}

1. Amrane, K., Geier, M., Corre, R., Léna, H., Léveiller, G., Gadby, F., Lamy, R., Bizec, J. L., Goarant, E., Robinet, G., Gouva, S., Quere, G., Abgral, R., Schick, U., Bernier, C., Chouaid, C., \& Descourt, R. (2020). First-line pembrolizumab for non-small cell lung cancer patients with $P D-L 1 \geqslant 50 \%$ in a multicenter real-life cohort: The PEMBREIZH study. Cancer medicine, 9(7), 2309-2316. https://doi.org/10.1002/cam4.2806 
2. Spira, A., \& Ettinger, D. S. (2004). Multidisciplinary management of lung cancer. The New England journal of medicine, 350(4), 379-392. https://doi.org/10.1056/NEJMra035536

3. Schiller, J. H., Harrington, D., Belani, C. P., Langer, C., Sandler, A., Krook, J., Zhu, J., Johnson, D. H., \& Eastern Cooperative Oncology Group (2002). Comparison of four chemotherapy regimens for advanced non-small-cell lung cancer. The New England journal of medicine, 346(2), 92-98. https://doi.org/10.1056/NEJMoa011954

4. Reck, M., Rodríguez-Abreu, D., Robinson, A. G., Hui, R., Csőszi, T., Fülöp A., Gottfried, M., Peled, N., Tafreshi, A., Cuffe, S., O’Brien, M., Rao, S., Hotta K., Leiby, M. A., Lubiniecki, G. M., Shentu, Y., Rangwala, R., Brahmer, J. R., \& KEYNOTE-024 Investigators (2016). Pembrolizumab versus Chemotherapy for PD-L1Positive Non-Small-Cell Lung Cancer. The New England journal of medicine, 375(19), 1823-1833. https://doi.org/10.1056/NEJMoa1606774

5. Brahmer J, Reckamp KL, Baas $\mathrm{P}$, et al. Nivolumab versus docetaxel in advanced squamous-cell non-small-cell lung cancer. N. Engl. J. Med. 2015; 373(2):123-135.

6. Borghaei H, Paz-Ares L, Horn L, et al. Nivolumab versus docetaxel in advanced nonsquamous non-small-cell lung cancer. N. Engl. J. Med. 2015;373(17):1627-1639.

7. Zhou, Y., Chen, C., Zhang, X., Fu, S., Xue, C., Ma, Y., Fang, W., Yang, Y., Hou, X., Huang, Y., Zhao, H., Hong, S., \& Zhang, L. (2018). Immune-checkpoint inhibitor plus chemotherapy versus conventional chemotherapy for first-line treatment in advanced non-small cell lung carcinoma: a systematic review and meta-analysis. Journal for immunotherapy of cancer, 6(1), 155-165. https://doi.org/10.1186/s40425-018-0477-9

8. Zhou, Y., Lin, Z., Zhang, X., Chen, C., Zhao, H., Hong, S., \& Zhang, L. (2019). First-line treatment for patients with advanced non-small cell lung carcinoma and high PD-L1 expression: pembrolizumab or pembrolizumab plus chemotherapy. Journal for immunotherapy of cancer, 7(1), 120. https://doi.org/10.1186/s40425-019-0600-6

9. Langer, C. J., Gadgeel, S. M., Borghaei, H., Papadimitrakopoulou, V. A., Patnaik, A., Powell, S. F., Gentzler, R. D., Martins, R. G. Stevenson, J. P., Jalal, S. I., Panwalkar, A., Yang, J. C., Gubens, M., Sequist, L. V., Awad, M. M., Fiore, J., Ge, Y., Raftopoulos, H., Gandhi, L., \& KEYNOTE-021 investigators (2016). Carboplatin and pemetrexed with or without pembrolizumab for advanced, non-squamous non-small-cell lung cancer: a randomised, phase 2 cohort of the open-label KEYNOTE-021 study. The Lance Oncology, 17(11), 1497-1508. https://doi.org/10.1016/S1470-2045(16)30498-3

10. Gandhi, L., Rodríguez-Abreu, D., Gadgeel, S., Esteban, E., Felip, E., De Angelis F., Domine, M., Clingan, P., Hochmair, M. J., Powell, S. F., Cheng, S. Y., Bischoff, H. G., Peled, N., Grossi, F., Jennens, R. R., Reck, M., Hui, R., Garon, E. B., Boyer, M., RubioViqueira, B., ... KEYNOTE-189 Investigators (2018). Pembrolizumab plus Chemotherapy in Metastatic Non-Small-Cell Lung Cancer. N. Engl. J. Med., 378(22), 2078-2092. https://doi.org/10.1056/NEJMoa1801005

11. Paz-Ares, L., Luft, A., Vicente, D., Tafreshi, A., Gümüș, M., Mazières, J., Hermes, B., Çay Șenler, F., Csőszi, T., Fülöp, A., Rodríguez-Cid, J., Wilson, J., Sugawara, S., Kato, T., Lee, K. H., Cheng, Y., Novello, S., Halmos, B., Li, X., Lubiniecki, G. M., ... KEYNOTE-407 Investigators (2018). Pembrolizumab plus Chemotherapy for Squamous Non-Small-Cell Lung Cancer. N. Engl. J. Med., 379(21), 2040-2051. https://doi.org/10.1056/NEJMoa1810865

12. Lopes G, Wu Y-L, Kudaba I, Kowalski D, Cho BC, Castro G, et al. (2018). Pembrolizumab (pembro) versus platinum-based chemotherapy (chemo) as first-line therapy for advanced/metastatic NSCLC with a PD-L1 tumor proportion score (TPS) $\geqslant 1 \%$ : Open-label, phase 3 KEYNOTE-042 study. J. Clin. Oncol., 36, LBA4-LBA. https://doi.org/10.1200/JCO.2018.36.18 suppl.LBA4.

13. Davies, J., Patel, M., Gridelli, C., de Marinis, F., Waterkamp, D., \& McCusker, M. E. (2017). Real-world treatment patterns for patients receiving second-line and third-line treatment for advanced non-small cell lung cancer: A systematic review of recently published studies. PloS one, 12(4), e0175679. https://doi.org/10.1371/journal.pone.0175679

14. Pinato, D. J., Shiner, R. J., White, S. D., Black, J. R., Trivedi, P., Stebbing J., Sharma, R., \& Mauri, F. A. (2016). Intra-tumoral heterogeneity in the expression of programmed-death (PD) ligands in isogeneic primary and metastatic lung cancer: Implications for immunotherapy. Oncoimmunology, 5(9), e1213934. https://doi.org/10.1080/2162402X.2016.1213934

15. Jimenez Alguilar E, Gainor J, Kravets S, Khosrowjerdi S, Lydon C, Adeni A, et al. (2018) MA04.05 outcomes in NSCLC patients treated with first-line Pembrolizumab and a PD-L1 TPS of $50-74 \%$ vs $75-100 \%$ or $50-89 \%$ vs $90-100 \%$. J. Thorac. Oncol. 13, S367-S8.

\section{Pembrolizumab is first-line treatment for patients with advanced non-small cell lung cancer in both mono and combination regimens}

Abstract. The development of inhibitors of immune checkpoints has radically changed the approaches of the treatment of patients with advanced non-small cell lung cancer (NSCLC), resulting in promising clinical outcomes. Pembrolizumab, a humanized monoclonal antibody, that is indicated as a first-line treatment for patients with advanced NSCLC with high PD-L1 expression (at least $50 \%$ of the tumor proportion score, TPS). Pembrolizumab in combination with chemotherapy has shown better clinical outcomes than chemotherapy as a first-line therapy for those patients.
However, little is known about the value of adding chemotherapy to pembrolizumab in this setting. This review represents data about an indirect comparison for pembrolizumab plus chemotherapy versus pembrolizumab. The main represented data were overall survival, progression-free survival and objective response rate. Data included results of 5 randomized trials involving almost 1300 patients were comparing pembrolizumab plus chemotherapy or pembrolizumab monotherapy against chemotherapy. Direct meta-analysis showed that both pembrolizumab plus chemotherapy and pembrolizumab alone improved clinical outcomes compared with chemotherapy. Indirect comparison showed that pembrolizumab plus chemotherapy was superior to pembrolizumab alone, in terms of objective response rate and progression-free survival. A trend towards improved overall survival was also observed. Thus, the addition of chemotherapy to pembrolizumab further improves the outcomes of patients with advanced NSCLC and a PD-L1 expression TPS of at least 50\%.

Keywords: Non-small cell lung cancer; Programmed cell deathligand 1; Pembrolizumab; Chemotherapy; First-line

\section{Пембролизумаб - первая линия терапии для пациентов с распространенным \\ немелкоклеточным раком легкого как в моно- так и в комбинированном режиме}

Резюме. Разработка ингибиторов точек (чекпойнтов) иммунного ответа радикально изменила подходы к лечению пациентов с распространенным немелкоклеточным раком легкого (НМРЛ), что привело к улучшению клинических результатов терапии. Пембролизумаб - гуманизированное моноклональное антитело, которое показано в качестве терапии первой линии у пациентов с распространенным НМРЛ и высоким уровнем экспрессии PD-L1 (не менее 50\% по шкале пропорции опухоли (tumor proportion score - TPS). Пембролизумаб в сочетании с химиотерапией продемонстрировал лучшие клинические результаты по сравнению с химиотерапией в качестве терапии первой линии у этой группы пациентов. Однако мало известно о значении добавления химиотерапии к лечению пембролизумабом у этих пациентов. Ниже приведен обзор литературы, в котором представлены данные косвенного сравнения пембролизумаба в сочетании с химиотерапией и монотерапии пембролизумабом. Основными данными, которые были приведены, были общая выживаемость, выживаемость без прогрессирования заболевания и уровень объективного ответа. Так, приведены данные метаанализа, который включал 5 рандомизированных клинических исследований, в которых приняли участие почти 1300 пациентов. Прямой метаанализ показал, что как пембролизумаб в сочетании с химиотерапией, так и монотерапия пембролизумабом улучшали клинические результаты по сравнению с химиотерапией. Косвенное сравнение показало, что пембролизумаб вместе с химиотерапией был лучше монотерапии пембролизумабом по показателям уровня объективного ответа и выживаемости без прогрессирования заболевания. Также наблюдалась тенденция к улучшению общей выживаемости. Таким образом, добавление химиотерапии к пембролизумабу еще больше улучшает результаты терапии пациентов с распространенным НМРЛ и высоким уровнем экспрессии PD-L1 - TPS не менее 50\%.

Ключевые слова: немелкоклеточный рак легкого; лиганд рецептора программируемой смерти клеток-1 (PD-L1); пембролизумаб; химиотерапия; первая линия терапии 